\title{
Organ Transplantation: An Overview from History to Challenges
}

\author{
Asad Razzaq* \\ Institute of Molecular Biology and Biotechnology, Bahauddin Zakariya University, Pakistan
}

Submission: August 11, 2018; Published: October 01, 2018

*Corresponding author: Asad Razzaq, Institute of Molecular Biology and Biotechnology, Bahauddin Zakariya University, Multan, Pakistan; Tel: +923064730096; Email: asadrazzaqlahore@gmail.com

Abstract

Organ transplantation is the best method for replacing damage organs and tissues. It has very long history but frequently work on it start in $18^{\text {th }}$ century. Now researchers are able to perform transplant easily and successfully. Take organ from donor that may be living or deceased. But the problem that matters a lot is that donor compatibility must be matched with the recipient. And the match occurs in very rare chances because perfect match found in identical twins. Rejection is a major problem for organ transplantation, but researchers control this problem by using specific type of drug name immunosuppressant that suppresses the immune response. Long term uses of immune suppressant also cause many diseases like diabetes, high cholesterol, high blood pressure etc.

Keywords: Immunosuppressant; Transplantation; Transplant rejection

\section{Introduction}

Organ transplantation is a successful technique for replacing damaged organ from healthy and fit organ. Organs may be damaged due to injury or some other factors. At $18^{\text {th }}$ century, researchers started their experiments on organ transplantation and they were failed many times and don't get their desired results. After many years, they were successful in organ transplantation. Researchers have able to do organ transplantation of kidney, liver, lung, heart, pancrease, cornea etc [1]. Organ transplantation are done on only those organ who have the ability to regenerate or those organ whose half number able to do full work like kidney, some portion of liver etc. Persons who donate their organs called donors and the persons who receive organ called recipients. Two common possibilities are present in organ transplantation. First is that both donor and recipient present at same place while second possibility is that both donor and recipient present at different places. Also, in some cases, transplantation occurs in same person and in some other cases, transplantation held in two different people [2]. It has a very long history. Some evidence found that people of past also do organ transplantation. Full history of transplantation is given here.

300 - Allotransplantation (transplantation occurs between two non-genetically identical people) was first originated in human in middle ages. Leg of church caretaker name Deacon Justinian was cut to treat cancer and attach leg of non-genetically identical person.

1668 - Bone graft was successfully grafted. For this purpose, dog skull used. This all procedure held in Holland. $\mathbf{1 7 4 6}$ - Nose successfully regrafted and this surgery is done by Dr. Garengeot in France.

1818 - A surgeon transfuses four-ounce blood from a man to his wife because she lost blood due to childbirth.

1878 - Human-human successfully bone transplant.

1869 - Successfully transplanted skin.

1906 - Cornea was successfully transplanted

1954 - Kidney was transplanted first time. Recipient is genetically identical twin.

1959 - Kidney transplantation occurs between fraternal twins.

1960 - Between Kidneys was transplanted [3].

1962 - Kidney, liver and lungs was removed from deceased person for transplantation.

1963 - Organs remove from brain dead person and use in transplantation.

1966 - Pancrease was successfully transplanted.

1967 - Liver transplantation performs successfully.

1967 - Heart was transplanted in U.S

1967 - Heart was transplanted in Saudi Arabia.

1968 - Bone Transplantation was successfully achieved. 


\section{International Journal of Cell Science \& Molecular Biology}

1968 - Harvard Ad Hoc Committee successfully developed a definition of brain-dead people.

1976 - First Immunosuppressant drug was successfully developed for minimize the risk of rejection by immune system. First immunosuppressant drug is cyclosporine [4,5].

1980 - Uniform Determination of Death Act (UDDA) developed the definition of death as stopping of circulatory/ respiratory systems or stops all function of the body.

1981 - Heart/Lung successfully transplanted.

1983 - First awareness week for national tissue and organ donors.

1983 - First workshop held on solid organ by a surgeon name General Everett Koop.

1984 - first combined Heart, Liver and Lungs transplantation done.

1984 - Congress passed an Act and banned selling of organs and tissues. Also make organ procurement network for equality of organ transplantation.

1986 - First contract for OPTN by ministry of health of U.S. OPTN work is to give facility that is totally based on equality.

1986 - Hospitals provide very good offers for close relatives of deceased person if they donate the organ of their deceased relative.

1987 — Intestine transplantation was successfully done

1988 - Split-Liver transplantation was successfully performed. The benefit of this procedure is that two recipient use liver of one donor.

1989 - Performed first small intestine transplantation.

1990 - Award noble prize to Dr. Joseph and Dr. Donnal Thomas for successful transplantation of kidney and bone respectively.

1990 - Living donor lung was used for transplantation.

1991 - National workshop on increasing donation of organs and tissue and this workshop is held by summon of General Antonia who is also a surgeon $[5,6]$.

1998 - Hand was successfully transplanted.

1998 - Plasmapheresis was injected in body and the purpose is that it helps to do transplant in those people who are not $\mathrm{ABO}$ compatible.

1999 - Act was passed for appreciating organ donor. According to this act, if employee wants leave for organ donation then they able to get full paid leave.

2001 - University of Louisville and Jewish Hospital successfully perform hand transplant.

2001 - Rate of living donors is increase as compare to deceased donor. And this was first time in U.S.
2002 - OPTN online the data of those patients who were waiting for organ.

2003 - April was nominated as Donation Life month.

2005 - In France, partial face was successfully transplanted.

2006 - IOM issue a report in which they tell us about ethical issues of transplantation and also tells us how deceased person donors will increase.

2006 - In U.S. 100 million people were registered as donor.

2008 - National Medal awarded for those who donate their organs.

2009 - A Campaign start that title is "END THE WAIT". This is due to increase the kidney donors to abolish waiting list of kidney recipients.

2010 - Full face was successfully transplanted.

2011 - Dr. Cavadas successfully transplant first double leg.

2014 - Uterine transplant successfully performed first time in Sweden.

2014 - In South Africa, penis was successfully transplanted [7-10].

As described earlier that it is successful technique for replacing damaged organ/tissue. Donors play a very good rule in transplantation because if donor not agrees to donate his organ/ tissue then doctors not able to do transplant. Donor has two types.

1. Living donor and

2. Deceased donor

If a living person donate their organ, then it is called living donor. If deceased person donates, then it is called deceased donor. Sometime person is cardiovascular dead and sometimes it is brain dead. If a doctor believed that this person is not more live, and they will die soon then they contact to person closest relative and suggest donating the patient's organs. If relative allow then doctor remove the patient organs and save it. Researchers have able to save human organ for five to six years. Cornea is the only organ that cannot be saved [3-11]. First doctor screens a person and check that whether a person is eligible for transplantation or not. If they found eligible then doctor advice a person to a specialist transplantation center. Doctors of transplantation center again screen a person and evaluate its health. Common process for transplantation is:

1. Cut the skin

2. Remove arteries and vessels that attach with organ.

3. Remove the organ

4. Take the new and healthy organ

5. Place it into the body

6. Attach arteries and vessels 
7. Close the skin cut [12].

A necessary thing is that instruments are sterilized. Now days, number of recipients is very high as compared to donors. People wait many years for organ/tissue. Sometime people died due to pain but cannot get any donor [13-15].

\section{Types of Transplantation}

There are six ways that are useful in transplantation of organ/ tissue.

1. Autograft

2. Allograft

3. Isograft

4. Xenograft

5. Domino transplant

6. Transplantation is Obese People

\section{Autograft}

Type of transplantation in which transplantation occurs within same subject. It occurs only in those tissues that have the ability to reproduce it or present in excess amount [16].

\section{Allograft}

Transplantation occurs in those people who are not genetically identical. Transplantation between genetically different people can causes many problems like tissue rejection because recognized the organ/tissue as foreign particle. Some tests are present that measure organ rejection e.g. Panel Reactive Antibody (PRA). PRA is simple test that check the person's blood. High PRA mean immune system make antibody against transplant organ/tissue. Higher PRA, higher chances of rejection.

\section{Isograft}

In this type, both donor and recipient are genetically identical (identical twins). Immune response cannot activate against this type of transplantation because both are genetically identical.

\section{Xenograft}

Transplantation occurs between two different species e.g. porcine heart valve. This type is unsafe as compared to others and rejection is very high. In addition, disease may also attack that person. A scientist name Eugene Gu study on transplant type that how heart of fetal can be transplanted into animal [18].

\section{Domino transplant}

This type is commonly applied on those who have cystic fibrosis disease. In CF, both lungs can be damaged. So, person needs lungs transplantation. Heart also transplanted in CF patient. The reason is that in some cases, one lung is large and other is small as a result, heart location is disturbed. This type of transplantation is very successful.

\section{In obese people}

As we know that obesity is the excess accumulation of fat.
Obesity directly disturbs the health and causes many diseases. Renal transplantation is not possible in obese people. In 2009, researchers work on obese people and successfully performed transplantation in obese by using Robotic technique [18].

\section{Types of Donation}

People donate their organ only for some reason. Some donate for their love ones and some donate due to need of money. Given are the important and common types of donation.

\section{Living related donor}

Close relatives donate their organ and tissue to their family member because they don't see their loved ones in pain and disease. That's why they donate organ and free their relative from pain [16].

\section{Good samaitan}

Some people donate their organ and tissues to unknown people and they do it for helping needy person and sometimes it is due to the need of money. Jesus Christian was the first people who donate their kidney to needy people [16-19].

\section{Financial Compensation}

Now days, organ transplantation is a business and people sell and buy organs. This method is very common in worldwide but this is illegal because donor demand money e.g. $16,000 \$$ for one kidney, 2000-4000\$ in Iran. It is localized in some countries like Australia. This method of donation is only acceptable in case of kidney only because research on people reported that people will able to survive with one kidney. Gary Becker reported that free donation could solve the problems of that people who cannot able to buy organ. He also gives an approximate calculation about human organ prices. Average market price is $15,000 \$$ for kidney, $32,000 \$$ for liver. In USA, human organ sale is banned while in Iran, it is legal since 1988 . About $40-50 \%$ people that live in different villages of Pakistan sale their one kidney for $2500 \$$ [15].

\section{Forced Donation}

Many organizations and authorities present in different regions of world that do business of selling and buying organs. World Medical Association gives a report that mostly prisoners organs missed, and this is due to because these organizations remove it forcefully. Another report that is given by Deputy Minister of Health China that approximately $95 \%$ organs that are used is transplantation are remove from prisoners. Another report given that almost half of the organ sources that are transplanted in last six years not know [13].

\section{Challenges}

Researchers and patients both face many different challenges. Many types of viruses are attacked when transplantation perform. Or sometimes very lethal disease comes due to instruments that cannot be sterilized. When private people forcefully remove the organ then they use those instruments that needs sterilization. Most common challenges are as fallow. 


\section{Transplant Rejection}

It is common problem that seen after most transplants. It is due to the attack of immune system that protects our body from different pathogens attacks that causes disease. It works very accurately. When any foreign particle or pathogen enter in body then the immune system active and check that whether a particle is self or non-self. If it identifies as non-self, then release specific proteins that are antibody for the destruction of that foreign particle and also remove that particle [20]. When doctors do surgery and transplant organ into body then immune system recognize it as non-self because particle that attaches on organ are different to those that are naturally present or organ. So, it releases immune response for destroy organ [21]. Sometimes, blood transfusion reaction occurs that make clogs of blood. Rejection has commonly three types.

\section{Hyperacute rejection}

This type of rejection occurs after few minutes of transplantation and it is only when organ and tissue not match with recipient. Person have blood group A and donor blood group is $\mathrm{B}$.

\section{Acute rejection}

Its time period is first week of transplantation to 3 months.

\section{Chronic rejection}

It occurs after many years of transplantation. Immune system slowly damages the organ/tissue that is transplanted [22]. Perfect matching of recipient and donor can reduce the rejection risk. But perfect match is not possible. $100 \%$ perfect match mean genetically identical and genetically identical are only twins. So, a doctor refers some drugs that suppress immune response, and these are called immunosuppressant minimize the chances of blood transfusion reactions. Cornea is the only part where blood transfusion not occurs because blood is not present [23]. It also has two types.

1. Induction drugs - doctor or surgeon uses this drug at a time of surgery.

2. Maintenance drug - it is use for long time for reducing the risk of rejection [24]. Maintenance drug further four types.

$\begin{aligned} \text { i. } & \text { Calcineurin Inhibitor } \\ \text { ii. } & \text { mTOR Inhibitor } \\ \text { iii. } & \text { Anti-Proliferative } \\ \text { iv. } & \text { Steroids }\end{aligned}$

These all are the type of maintenance drug and doctor recommends it. But it is also not good for health. Its long-term use causes many diseases like;

a. 100-degree fever

b. Severe cold and cough

c. Burning feels in urine
These are some symptoms that indicates that amount of immunosuppressant is high in blood. If not notice these symptoms, then risk of lethal disease is present. So, go to the transplant center and tells doctor about symptoms and feeling [25,26].

\section{Diabetes}

Diabetes also diagnosed in some cases. And the reason is high amount of immunosuppressant in blood.

\section{High Cholestrol}

No symptoms occur at start but it's dangerous for health. It creates clogs and blocked the blood vessels. So, blood can't reach every site due to clog that causes many diseases like paralysis etc. [27].

\section{Gastro-Intestinal Problems}

It's due to steroids that doctor recommends us as an immunosuppressant [28].

\section{Sexual Problem}

Sex drive becomes low due to high amount of immunosuppressant in blood.

Some other diseases also occur like bones week, anxiety, hair loss, anemia, puffy face etc. $[19,21]$

\section{Cost}

In transplantation, cost is matters a lot. Some people sell their organs and their cost is very high. Also illegal authorities also active and involve in selling and buying organs. Price of kidney in different countries of world like, in Manila, its price is 1000$2000 \$$, America $(10,000 \$)$, South Africa $(20,000 \$)$ and China $(70,000 \$)$. These prices are not affordable for poor person [29].

\section{Safety}

Transplant technique is control by FDA that makes very strict laws. Use of un-sterilize instruments causes many lethal diseases like HIV, hepatitis B, C. In past, a person who suffered Hepatitis B and $C$ donate their organs to needy and poor people. Doctors don't screen the donor and transplant the organs without checking it. So, FDA makes laws and regulate transplant technique. People who suffer from lethal diseases (diabetes, AIDS, Hepatitis) are not able to donate their organs and tissues for transplantation [30].

\section{Conclusion}

Organ transplantation is basically a replacing of damaged organ. Organs are damage due to some injury or any other problem like a disease. Workers take organ from donor that may be living or deceased and transplant it into recipient. Donor donate their organ for many reasons like for loved one, forced donation, for money, etc. In many countries, organ selling is illegal like in America, but in some countries, it is legal like in Iran. About $90 \%$ organs are removed from prisoners who were not able to take decisions and the authorities remove their organs forcefully that increase the chance of disease transfer like HIV, Hepatitis B \& C, etc. We are able to reduce these risks by using sterilized 
instruments and also screen the donor for HIV, Hepatitis B \& C, etc, before removing organ. After transplant, some issues occur like rejection, diabetes, high cholesterol etc. Doctors refer some immunosuppressant for reducing the risk of rejection. But longterm use of immunosuppressant causes many diseases like high blood pressure, anxiety, etc.

\section{Declarations}

\section{Ethics Approval and Consent to Participate}

Not Applicable.

\section{Consent for Publication}

Not Applicable.

\section{Availability of Data and material}

Not applicable.

\section{Competing Interests}

Not Applicable

\section{Funding}

Cannot receive any fund for this study.

\section{Patient Consent}

Not Applicable

\section{Acknowledgement}

Not applicable.

\section{References}

1. Sixty-Third World Health Assembly, World Health Organization (2010) WHO Guiding Principles on Human Cell, Tissue and Organ Transplantation. Cell Tissue Bank 11(4): 413-419.

2. WHO (2011) Organ trafficking and transplantation pose new challenges. World Health Organization, Geneva, Switzerland.

3. Lawler RH (1982) Pioneer Of Kidney Transplants - The New York Times.

4. A Science Odyssey: People and Discoveries: First successful kidney transplant performed.

5. History | UNOS. (2018)

6. History of Organ Donation and Transplants | organdonor.gov (2018).

7. Joseph Netto (2015) Doctors claim first successful penis transplant CNN.

8. MONIKA SCISLOWSKA (2013) Polish man gets quick face transplant after injury.

9. Woman to give birth after first ovary transplant pregnancy. Support the Guardian.

10. Man rejects first penis transplant. Support| the Guardian.

11. Frohn C, Fricke L, Puchta J, Kirchner H (2001) The effect of HLA-C matching on acute renal transplant rejection. Nephrol Dial Transplant 16(2): 355-360.
12. Gloor J, Stegall MD (2010) Sensitized renal transplant recipients: current protocols and future directions. Nat Rev Nephrol [Internet] 6(5): 297-306.

13. Wolfe RA, Merion RM, Roys EC, Port FK (2010) Trends in Organ Donation and Transplantation in the United States 9(4 pt 2): 869-878.

14. Greer DM, Varelas PN, Haque S, Wijdicks EFM (2008) Variability of brain death determination guidelines in leading US neurologic institutions. Neurology 70(4): 284-289.

15. Leichtman AB, McCullough KP, Wolfe RA (2011) Improving the Allocation System for Deceased-Donor Kidneys. N Engl J Med 364(14): 1287-1279.

16. Nathan HM, Conrad SL, Held PJ, McCullough KP, Pietroski RE, et al. (2003) Organ donation in the United States. Am J Transplant: 29-40.

17. Oberholzer J, Giulianotti P, Danielson KK, Spaggiari M, Bejarano Pineda L, et al. (2013) Minimally Invasive Robotic Kidney Transplantation for Obese Patients Previously Denied Access to Transplantation. Am J Transplant [Internet] 13(3): 721-728.

18. Howard RJ, Schold JD, Cornell DL (2005) A 10-year analysis of organ donation after cardiac death in the United States. Transplantation 80(5): 564-568.

19. Dutkowski P, Linecker M, De Oliveira ML, Müllhaupt B, Clavien PA (2015) Challenges to liver transplantation and strategies to improve outcomes. Gastroenterology 148(2): 307-323.

20. Dew MA, Rosenberger EM, Myaskovsky L, DiMartini AF, DeVito Dabbs AJ, et al. (2015) Depression and Anxiety as Risk Factors for Morbidity and Mortality After Organ Transplantation: A Systematic Review and Meta-Analysis. Transplantation 100(5): 988-1003.

21. Beyar R (2011) Challenges in organ transplantation. Rambam Maimonides Med 2(2): e0049.

22. Wiseman AC (2016) Immunosuppressive Medications. Clin J Am Soc Nephrol11(2): 332-343.

23. Hartono C, Muthukumar T, Suthanthiran M (2013) Immunosuppressive drug therapy. Cold Spring Harb Perspect Med 3(9): a015487.

24. Bethany Pellegrino, Rebecca J Schmidt SO (2016) Immunosuppression: Overview, History, Drugs.

25. Halloran PF (2004) Immunosuppressive Drugs for Kidney Transplantation. N Engl J Med 351(26): 2715-2729.

26. Mc Donald Hyman C, Turka LA, Blazar BR (2015) Advances and challenges in immunotherapy for solid organ and hematopoietic stem cell transplantation. Sci Transl Med 7(280): 280rv2.

27. Saidi RF, Hejazii Kenari SK (2014) Challenges of organ shortage for transplantation: solutions and opportunities. Int J organ Transplant Med 5(3): 87-96.

28. Tuttle Newhall JE, Krishnan SM, Levy MF, Mc Bride V, Orlowski JP, et al. (2004) Organ Donation and Utilization in the United States 9(4 pt 2): 879-893.

29. Berg CL, Steffick DE, Edwards EB, Heimbach JK, Magee JC, et al. (2008) Liver and Intestine Transplantation in the United States 1998-2007. Am J Transplant 9(4 pt 2): 907-931. 


\section{Your next submission with Juniper Publishers will reach you the below assets}

- Quality Editorial service

- Swift Peer Review

- Reprints availability

- E-prints Service

- Manuscript Podcast for convenient understanding

- Global attainment for your research

- Manuscript accessibility in different formats

( Pdf, E-pub, Full Text, Audio)

- Unceasing customer service

Track the below URL for one-step submission https://juniperpublishers.com/online-submission.php 